TECHNICAL TRANSACTIONS 2/2017

CZASOPISMO TECHNICZNE 2/2017

CHEMISTRY

DOI: 10.4467/2353737XCT.17.017.6210

\author{
Barbara Michorczyk (bmichorczyk@chemia.pk.edu.pl) \\ Elżbieta Hędrzak \\ Institute of Organic Chemistry and Technology, Faculty of Chemical Engineering \\ and Technology, Cracow University of Technology
}

\title{
STUDY OF OXIDATIVE COUPLING OF METHANE INTEGRATED WITH CO
}

\section{OXIDATION}

BADANIE PROCESU UTLENIAJĄCEGO SPRZĘGANIA METANU

ZINTEGROWANEGO Z DOPALANIEM CO

\begin{abstract}
In this work, the process of OCM carried out over $\mathrm{Mn}-\mathrm{Na}_{2} \mathrm{WO}_{4} / \mathrm{SiO}_{2}$ integrated with selective oxidation over Ag/support was investigated. the effect of feed gas composition and OCM bed temperature as well as the position of $\mathrm{Ag} /$ support bed and additional oxygen injection before this bed were investigated. At optimal OCM conditions for the $\mathrm{Mn}-\mathrm{Na}_{2} \mathrm{WO}_{4} / \mathrm{SiO}_{2}$ catalyst $\left(\mathrm{CH}_{4} / \mathrm{O}_{2}=3.75 ; V_{\text {tot }}=77 \mathrm{~cm}^{3} / \mathrm{min} ; \mathrm{T}=780^{\circ} \mathrm{C}\right)$, the injection of additional $4 \mathrm{~cm}^{3} / \mathrm{min}$ of oxygen into the bed of $\mathrm{Ag} /$ support (working at $250-300^{\circ} \mathrm{C}$ ) leads to a preferential oxidation of $\mathrm{CO}$ to $\mathrm{CO}_{2}$.
\end{abstract}

Keywords: oxidative coupling of methane, integration with oxidation, ethylene, silver catalyst

\section{Streszczenie}

W pracy zbadano proces $\mathrm{OCM}$ w obecności $\mathrm{Mn}-\mathrm{Na}_{2} \mathrm{WO}_{4} / \mathrm{SiO}_{2}$ zintegrowanywjednym reaktorze zprocesem selektywnego utleniania $\mathrm{CO}$ prowadzonym na katalizatorze Ag/nośnik. Zbadano wplyw zmiany parametrów prowadzenia procesu OCM, takich jak skład surowca i temperatury oraz efekt dodatku tlenu nad złoże $\mathrm{Ag} /$ nośnik. Wykazano, że w optymalnej temperaturze pracy złoża OCM $\left(\mathrm{CH}_{4} / \mathrm{O}_{2}=3,75 ; V_{\text {cal }}=77 \mathrm{~cm}^{3} /\right.$ min; $T=780^{\circ} \mathrm{C}$ ) wprowadzenie dodatkowo $4 \mathrm{~cm}^{3} /$ min tlenu nad złoże Ag/nośnik (pracującego w temp. $250-300^{\circ} \mathrm{C}$ ) prowadzi do preferencyjnego utleniania $\mathrm{CO}$ do $\mathrm{CO}_{2}$.

Słowa kluczowe: utleniające sprzęganie metanu, integracja z utlenianiem, etylen, katalizatory srebrowe 


\section{Introduction}

The direct conversion of methane to useful chemical intermediates, such as hydrocarbons (saturated, unsaturated and aromatic), methanol and formaldehyde, is one of the topics. Among all these direct processes, the closest one to commercialization is the oxidative coupling of methane (OCM) to ethylene and ethane $[1,2]$. However, a still low per-pass conversion of methane (below $20-30 \%$ ) in order to achieve high selectivity $(70-80 \%$ ) as well as stability of catalysts at high reaction temperatures $\left(780-850^{\circ} \mathrm{C}\right)$ limits its industrial implementation [3].

An integration of OCM with other processes may improve the attractiveness of this process. Up to now, most attention was devoted to the integration of the OCM process with dry and steam reforming of methane [2, 4-9]. Several other possibilities for the integration of OCM with aromatization [10-12], benzene alkylation [13], pyrolysis [14], conversion to acetic acid and/or ethanol [15], synthesis Fischer-Tropscha [16], oxidative dehydrogenation of ethane $[12,17-19]$, methanation of $\mathrm{CO}_{x}[20,21]$ were also explored.

An interesting issue can also be the integration of $\mathrm{OCM}$ with a selective oxidation of $\mathrm{CO}$ to $\mathrm{CO}_{2}$. Such coupling of two exothermic reactions in one reactor (two catalytic beds in one reactor) can be attractive from the technological point of view. The combustion of $\mathrm{CO}$, which is produced on an OCM bed as a by-product, may simplify the separation of the reaction mixture. The total conversion of $\mathrm{CO}$ to $\mathrm{CO}_{2}$ should especially facilitate $\mathrm{CH}_{4}$ recycling as perpass conversion of methane that does not exceed $30 \%$. In the case of the most promising catalysts, e.g. $\mathrm{Mn}-\mathrm{Na}_{2} \mathrm{WO}_{4} / \mathrm{SiO}_{2}$ other by-products, such as $\mathrm{CO}_{2}$ and water, it has no negative impact on the OCM process, so, in many cases, it is not required to clean the recycled methane from these gases, which can be used as a diluent [22-24]. However, in the case of integration in a single reactor, there are several problems due to the presence of many chemical compounds in the stream leaving the OCM catalyst bed, which e.g. may cause a deactivation of the $\mathrm{CO}$ oxidation catalyst. Moreover, hydrocarbon products and unreacted methane on a $\mathrm{CO}$ oxidation bed can be oxidized. Thus, the selection of a suitable catalyst is difficult because, usually, the catalysts active in the oxidation of $\mathrm{CO}$ also catalyze the total oxidation of hydrocarbons. An alternative solution can be the separation of ethylene and ethane from the reaction mixture before oxidation of $\mathrm{CO}$ to $\mathrm{CO}_{2}$, but this solution requires an additional reactor for $\mathrm{CO}$ oxidation, which increases the amount of operations.

There are many catalysts active in the selective oxidation of $\mathrm{CO}$ to $\mathrm{CO}_{2}$. A lot of noble metalbased catalysts, especially of the platinum group [25-29] and ones that are gold-based [2933 ] as well as non-noble metal oxide-based catalysts (e.g. containing $\mathrm{CoO}, \mathrm{CuO}$ and $\mathrm{MnO}_{x}$ ) $[28,34-39]$ have been investigated. Unfortunately, most of these catalysts are active not only in the oxidation of $\mathrm{CO}$ to $\mathrm{CO}_{2}$, but also in the oxidation of hydrocarbons [40]. For example, methane in the presence of a catalyst based on $\mathrm{Pd}$ can be oxidized even at around $300^{\circ} \mathrm{C}$ [41].

Our attention turned to silver-based catalysts. These catalysts have been recognized to show a relatively high activity in the oxidation of $\mathrm{CO}$ and a low activity in the oxidation of $\mathrm{CH}_{4}[42,43]$. In this work, we have investigated the integration of the OCM process over $\mathrm{Mn}-\mathrm{Na}_{2} \mathrm{WO}_{4} / \mathrm{SiO}_{2}$ multicomponent catalyst with selective $\mathrm{CO}$ oxidation over $\mathrm{Ag}$ / 
$\mathrm{SiO}$ or $\mathrm{Ag} / \mathrm{Al}_{2} \mathrm{O}_{3}$ in one reactor. the effects of the feed gas composition $\left(\mathrm{CH}_{4} / \mathrm{O}_{2}\right.$ ratio, $\mathrm{O}_{2}$ addition below second bed) and temperature on the product distribution and the conversion of substrates were carefully investigated.

\section{Experimental}

\subsection{Catalyst preparation}

The OCM catalyst $\left(\mathrm{Mn}-\mathrm{Na}_{2} \mathrm{WO}_{4} / \mathrm{SiO}_{2}\right)$ was prepared by incipient wetness impregnation. Dry $\mathrm{SiO}_{2}$ (Aldrich) was impregnated in two steps with an aqueous solution of $\mathrm{Mn}\left(\mathrm{NO}_{3}\right)_{2} \times$ $4 \mathrm{H}_{2} \mathrm{O}$ (POCh - Polish Reagents) and $\mathrm{Na}_{2} \mathrm{WO}_{4}$ (Aldrich), respectively. In a typical procedure, $1 \mathrm{~g}$ of silica was impregnated with $1 \mathrm{~cm}^{3}$ of aqueous solutions containing the desirable content of each salt needed for obtaining 2 and $5 \mathrm{wt} . \%$ of $\mathrm{Mn}$ and $\mathrm{Na}_{2} \mathrm{WO}_{4}$, sequentially. After each impregnation, the materials were dried for $8 \mathrm{~h}$ at $120^{\circ} \mathrm{C}$ and calcined at $900^{\circ} \mathrm{C}$ for $8 \mathrm{~h}$.

The catalysts of total oxidation $\left(\mathrm{Ag} / \mathrm{SiO}_{2}\right.$ and $\left.\mathrm{Ag} / \mathrm{Al}_{2} \mathrm{O}_{3}\right)$ were also prepared by impregnation. Dry $\mathrm{SiO}_{2}$ (Aldrich) and $\gamma-\mathrm{Al}_{2} \mathrm{O}_{3}$ (Aldrich) supports were impregnated with aqueous solutions of $\mathrm{AgNO}_{3}$ (Polish Chemical Reagents). The content of precursor in the solution was desirable for obtaining $15-\mathrm{wt} . \%$ of $\mathrm{Ag}$. the thermal pretreatment procedures and conditions were the same as in the case of the OCM catalyst.

\subsection{Catalytic performance}

Catalytic tests were carried out in a flow-type tubular quartz reactor with the dimensions of (internal diameter $) \times($ length $) \times($ wall thickness $)=8 \times 270 \times 1 \mathrm{~mm}$. Before the process, the catalyst placed in the reactor was heated in dry helium for $30 \mathrm{~min}$ at $800^{\circ} \mathrm{C}$. The weight of the catalyst was $400 \mathrm{mg}$ (grain size $0.2-0.3 \mathrm{~mm}$ ) and the temperature of the process was in the range between $730-800^{\circ} \mathrm{C}$. The reactor was fed with the mixture of $\mathrm{CH}_{4}: \mathrm{O}_{2}: \mathrm{He}=3.75: 1: 2,8$, and $\mathrm{CH}_{4}: \mathrm{O}_{2}: \mathrm{He}=2.5: 1: 4,8$. The total volumetric flow rate was $77 \mathrm{~cm}^{3} / \mathrm{min}$ in all runs. The reagents mixture was analyzed using the Agilent $6890 \mathrm{~N}$ gas chromatograph equipped with two columns (molecular sieve 5A for separation of $\mathrm{CO}$ and $\mathrm{O}_{2}$ and Hayesep $Q$ for separation of $\mathrm{H}_{2}, \mathrm{CO}_{2}$, $\mathrm{H}_{2} \mathrm{O}$, and hydrocarbons) and thermal conductivity detectors.

The conversion of methane $\left(X_{m}\right)$ and selectivity to $i$-th product $\left(S_{i}\right)$ were calculated according to the following formulas:

where:

$$
X_{M}=\frac{n_{M(\text { inlet })}-n_{M(\text { outlet })}}{n_{M(\text { inlet })}} \cdot 100 \% \quad S_{i}=\frac{\sum a_{i} \cdot n_{i}}{n_{M(\text { inlet })}-n_{M(\text { outle })}} \cdot 100 \%
$$

$n_{M(\text { inlet) }}, n_{M(\text { outlet) }}$ - the numbers of methane moles in the inlet and the outlet of the reactor, respectively;

$n_{i}$ - the number of moles of the $\mathrm{i}$-th product in the outlet

$a_{i}$ - the number of carbon atoms in the " $i$ " product (ethane, ethene, propane and propene). 


\section{Results and discussion}

\subsection{Effect of additional bed position}

Figure 1 illustrates the position of the oxidative coupling of methane $\left(\mathrm{Mn}-\mathrm{Na}_{2} \mathrm{WO}_{4} /\right.$ $\mathrm{SiO}_{2}$ ) and the $\mathrm{CO}$ oxidation catalyst beds in a tubular flow-type quartz reactor. the bed of $\mathrm{CO}$ oxidation is located below the OCM band.

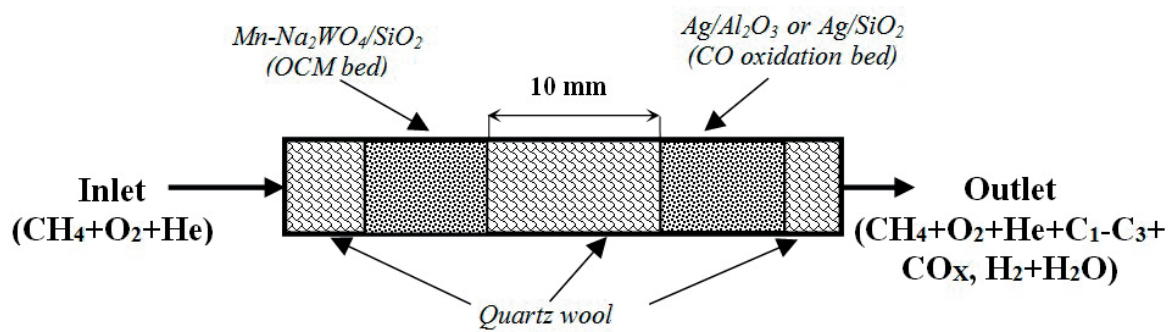

Fig. 1. Scheme illustrating $\mathrm{Mn}-\mathrm{Na}_{2} \mathrm{WO}_{4} / \mathrm{SiO}_{2}$ and $\mathrm{Ag} /$ support bed positions in the flow-type tubular reactor

Table 1 summarizes the catalytic results obtained in the presence and absence of an additional $\mathrm{CO}$ oxidation catalyst as a function of temperature. To clarify the effect of integration (in two separated beds), additional catalytic tests concerning the mixture of OCM and CO oxidation catalysts (in one bed) were investigated as well. A comparison of results obtained in the absence and presence of additional $\mathrm{CO}$ oxidation bed reveals that above $750^{\circ} \mathrm{C}$ the integration of $\mathrm{OCM}$ with $\mathrm{CO}$ oxidation in a separate bed exerts a small positive effect on methane conversion and selectivity to $\mathrm{C}_{2+}$. In contrast, at $750^{\circ} \mathrm{C}$ and below this temperature, the integration exerts a significant negative influence on the product distribution. the dramatic difference in the catalytic behavior vs. temperature can be explained based on oxygen conversion over the OCM bed (in single OCM process). It is clear from table 1 that, above $750^{\circ} \mathrm{C}$, oxygen reacts in $100 \%$ over the OCM bed; therefore, the second $\mathrm{CO}$ oxidation bed $\left(\mathrm{Ag} / \mathrm{SiO}_{2}\right)$ has an insignificant effect on product distribution and methane conversion. the situation changes at $750{ }^{\circ} \mathrm{C}$ and $730{ }^{\circ} \mathrm{C}$ when unreacted oxygen appears in the mixture on the exit of the OCM bed. This oxygen reacts with $\mathrm{CO}$ and $\mathrm{C}_{2+}$ hydrocarbons over $\mathrm{Ag} / \mathrm{SiO}_{2}$ catalyst; therefore, the selectivity to $\mathrm{CO}$ and $\mathrm{C}_{2+}$ decrease significantly.

A similar explanation can be adopted for results obtained in the presence of mixed $\mathrm{Mn}-\mathrm{Na}_{2} \mathrm{WO}_{4} / \mathrm{SiO}_{2}$ and $\mathrm{Ag} / \mathrm{SiO}_{2}$ catalysts (denoted in Table 1 as $\mathrm{Mn}-\mathrm{Na}_{2} \mathrm{WO}_{4} / \mathrm{SiO}_{2}+\mathrm{Ag}$ / $\mathrm{SiO}_{2}$ ). Because $\mathrm{Ag} / \mathrm{SiO}_{2}$ catalyst is mixed with $\mathrm{Mn}-\mathrm{Na}_{2} \mathrm{WO}_{4} / \mathrm{SiO}_{2}$, it has permanent contact with oxygen at any investigated temperature; therefore, the selectivity to $\mathrm{C}_{2+}$ hydrocarbons in the presence of mixed catalysts (in one bed) is always lower than in the presence single $\mathrm{Mn}-\mathrm{Na}_{2} \mathrm{WO}_{4} / \mathrm{SiO}_{2}$ catalyst or in the integrated process carried out above $750^{\circ} \mathrm{C}$.

The above results indicate that the reaction conditions optimal for the OCM process are not optimal for selective $\mathrm{CO}$ oxidation over $\mathrm{Ag} / \mathrm{SiO}_{2}$ catalyst. In the integrated process, 





the $\mathrm{Ag} / \mathrm{SiO}_{2}$ catalyst participates not only in $\mathrm{CO}$ oxidation, but also in the total oxidation of hydrocarbons. the range of temperature between $730-800^{\circ} \mathrm{C}$ is too high for selective $\mathrm{CO}$ oxidation.

Assuming initial catalytic results in the next parts of the experiments, we modified the conditions of the second $\mathrm{CO}$ oxidation bed by changing the positions of the $\mathrm{Ag} / \mathrm{SiO}_{2}$ bed (change of temperature) or by adding oxygen after the OCM bed (feed gas modification). the modifications are schematically presented in Figure 2.

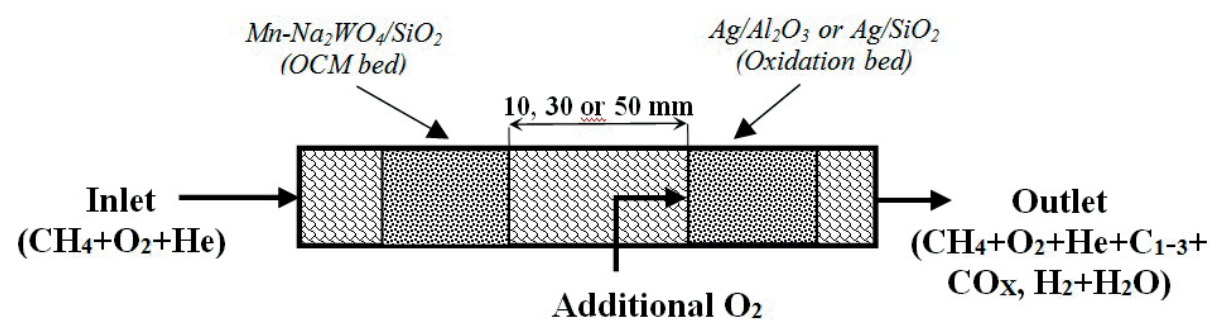

Fig. 2. Scheme illustrates $\mathrm{Mn}-\mathrm{Na} 2 \mathrm{WO} 4 / \mathrm{SiO} 2$ and $\mathrm{Ag} /$ support bed positions in the flow-type tubular reactor as well as modifications in the bed position and feed gas composition injected into the second bed zone

The results obtained after the modifications are reported in Table 2. the process of OCM in the presence and absence of $\mathrm{CO}$ oxidation bed was carried out using a feed mixture with $\mathrm{CH}_{4} / \mathrm{O}_{2}=3.8$ molar ratio at two different temperatures. In selected cases, a silver catalyst supported with $\gamma-\mathrm{Al}_{2} \mathrm{O}_{3}$ was investigated as well. It is clear from Table 2 that the modification of the second bed position gives an insignificant effect when $\mathrm{O}_{2}$ is converted in $100 \%$ over the OCM bed (e.g. at $780^{\circ} \mathrm{C}$ ). The integration effect can be improved either by decreasing $\mathrm{CO}$ oxidation bed temperature or by $\mathrm{O}_{2}$ co-feeding. In most cases, a change of the oxidation bed position (decrease of the temperature) leads to the preferential CO oxidation. Such a modification enhances the selectivity to $\mathrm{C}_{2+}$ hydrocarbons.

A similar effect of $\mathrm{CO}$ oxidation without a significant change in the selectivity to $\mathrm{C}_{2+}$ hydrocarbons is also observed in the case of $\mathrm{Ag} / \mathrm{Al}_{2} \mathrm{O}_{3}$, which is an industrial catalyst for selective oxidation of ethene to ethylene oxide. It should be pointed out that, under the reaction conditions investigated in this work, any additional products of partial oxidation of ethene, ethane or methane are formed.

The best effect of integration is achieved when the OCM process is carried out at $780^{\circ} \mathrm{C}$ and the bed of $\mathrm{CO}$ oxidation is located at the end of the oven where the temperature drops to $230-250^{\circ} \mathrm{C}$. In such conditions, the injection of additional $4 \mathrm{~cm}^{3} / \mathrm{min}$ of oxygen leads to almost complete $\mathrm{CO}$ oxidation without $\mathrm{C}_{2+}$ selectivity changes. Nevertheless, even at such a low temperature, we did not observe any additional oxygenates in the product mixture, such as ethylene oxide or acetaldehyde. Further experiments concerning the modification of the oxidation catalyst composition and the optimization its work conditions as well as the influence of gaseous promoters are now in progress. 


\begin{tabular}{|c|c|c|c|c|c|c|c|c|c|c|}
\hline 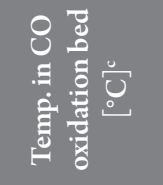 & 1 & $\begin{array}{l}\vec{a} \\
\stackrel{1}{1} \\
\stackrel{n}{n}\end{array}$ & $\begin{array}{l}\text { के } \\
\text { 1े } \\
\stackrel{q}{q}\end{array}$ & $\begin{array}{l}\overrightarrow{\hat{A}} \\
\hat{w} \\
\tilde{y}\end{array}$ & $\begin{array}{l}\infty \\
0 \\
1 \\
\infty \\
0 \\
0\end{array}$ & $\begin{array}{l}\hat{0} \\
0 \\
1 \\
\infty \\
\text { dे }\end{array}$ & 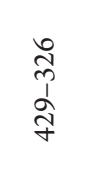 & 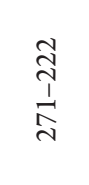 & 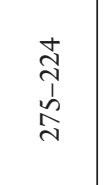 & 1 \\
\hline 至 & $\begin{array}{l}0 \\
\hat{e} \\
\vdots \\
0 \\
\infty\end{array}$ & $\begin{array}{l}\tilde{n} \\
\vdots \\
o \\
\infty\end{array}$ & $\begin{array}{l}\infty \\
\hat{n} \\
1 \\
0 \\
\infty\end{array}$ & $\begin{array}{l}0 \\
0 \\
1 \\
0 \\
\infty\end{array}$ & $\begin{array}{l}\frac{a}{N} \\
0 \\
0 \\
\infty \\
\infty\end{array}$ & \begin{tabular}{l} 
\pm \\
\multirow{2}{*}{} \\
0 \\
$\infty$ \\
$\infty$
\end{tabular} & \begin{tabular}{l}
0 \\
\multirow{1}{1}{} \\
$i$ \\
0 \\
$\infty$
\end{tabular} & $\begin{array}{l}n \\
\hat{n} \\
0 \\
\infty \\
\infty\end{array}$ & $\begin{array}{l}n \\
\hat{n} \\
0 \\
\infty \\
\infty\end{array}$ & 1 \\
\hline 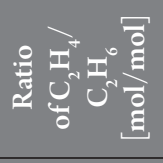 & $\stackrel{+}{-}$ & $\cong$ & $\stackrel{+}{-}$ & $\stackrel{+}{-}$ & $\because$ & $\because$ & $\stackrel{\infty}{\circ}$ & $\because$ & $\because$ & $\stackrel{+}{-}$ \\
\hline 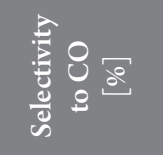 & 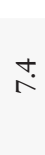 & $\vec{\infty}$ & $\stackrel{?}{\sim}$ & $\stackrel{\circ}{+}$ & 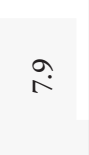 & $\stackrel{\infty}{\stackrel{-}{-}}$ & rֶ. & ${ }_{\infty}^{\circ}$ & $\grave{i}$ & $\tilde{\sigma}$ \\
\hline 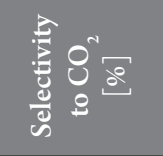 & $\stackrel{?}{\sim}$ & $\stackrel{\circ}{\stackrel{+}{\sim}}$ & $\stackrel{\sim}{\vec{\sim}}$ & $\stackrel{\infty}{\dot{m}}$ & $\stackrel{n}{\mathrm{~N}}$ & ָై & 官 & ते & aे & $\begin{array}{l}0 \\
\stackrel{\infty}{\infty}\end{array}$ \\
\hline 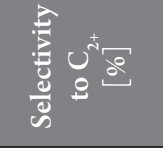 & $\vec{\infty}$ & $\stackrel{\hat{\hat{\sigma}}}{0}$ & $\begin{array}{l}\infty \\
\dot{0} \\
\dot{0}\end{array}$ & 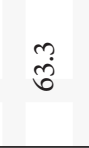 & శ̊. & $\begin{array}{l}\dot{\Delta} \\
\dot{b}\end{array}$ & $\stackrel{n}{f}$ & $\stackrel{\partial}{\dot{\delta}}$ & $\frac{2}{8}$ & $\stackrel{\infty}{\dot{b}}$ \\
\hline 造 & $\vec{\infty}$ & $\vec{a}$ & @ & @ & $\stackrel{-}{\circ}$ & 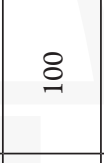 & $\stackrel{-}{\circ}$ & $\nsubseteq$ & $\tilde{\infty}$ & 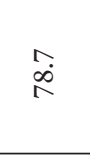 \\
\hline 章 & 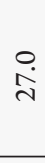 & $\stackrel{+}{\stackrel{\Delta}{\Delta}}$ & $\begin{array}{l}0 \\
\stackrel{\sim}{N}\end{array}$ & $\stackrel{a}{\vec{\lambda}}$ & $\stackrel{\infty}{\stackrel{\infty}{\sim}}$ & $\underset{\infty}{\sim}$ & $\vec{\infty}$ & $\stackrel{\infty}{\stackrel{\infty}{\sim}}$ & $\stackrel{?}{\sim}$ & $\underset{\sim}{\stackrel{\Delta}{\Delta}}$ \\
\hline 言它 & & & & & & $\stackrel{\triangleright}{\curvearrowright}$ & & & & \\
\hline 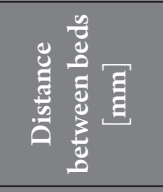 & 1 & 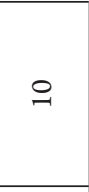 & ஓ & D & 凩 & 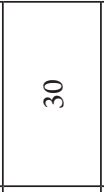 & ి & in & in & in \\
\hline  & 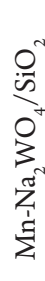 & 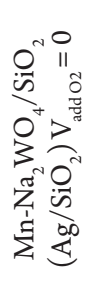 & 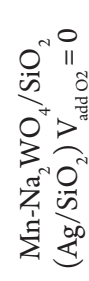 & 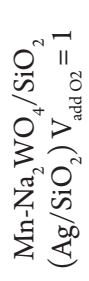 & 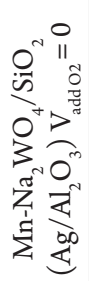 & 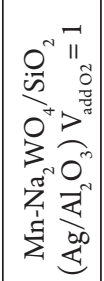 & 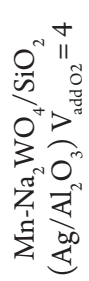 & 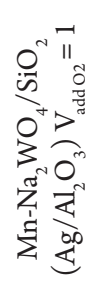 & 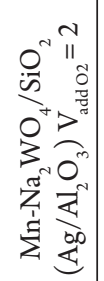 & 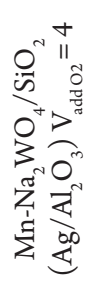 \\
\hline
\end{tabular}


$\frac{N}{\tilde{0}}$

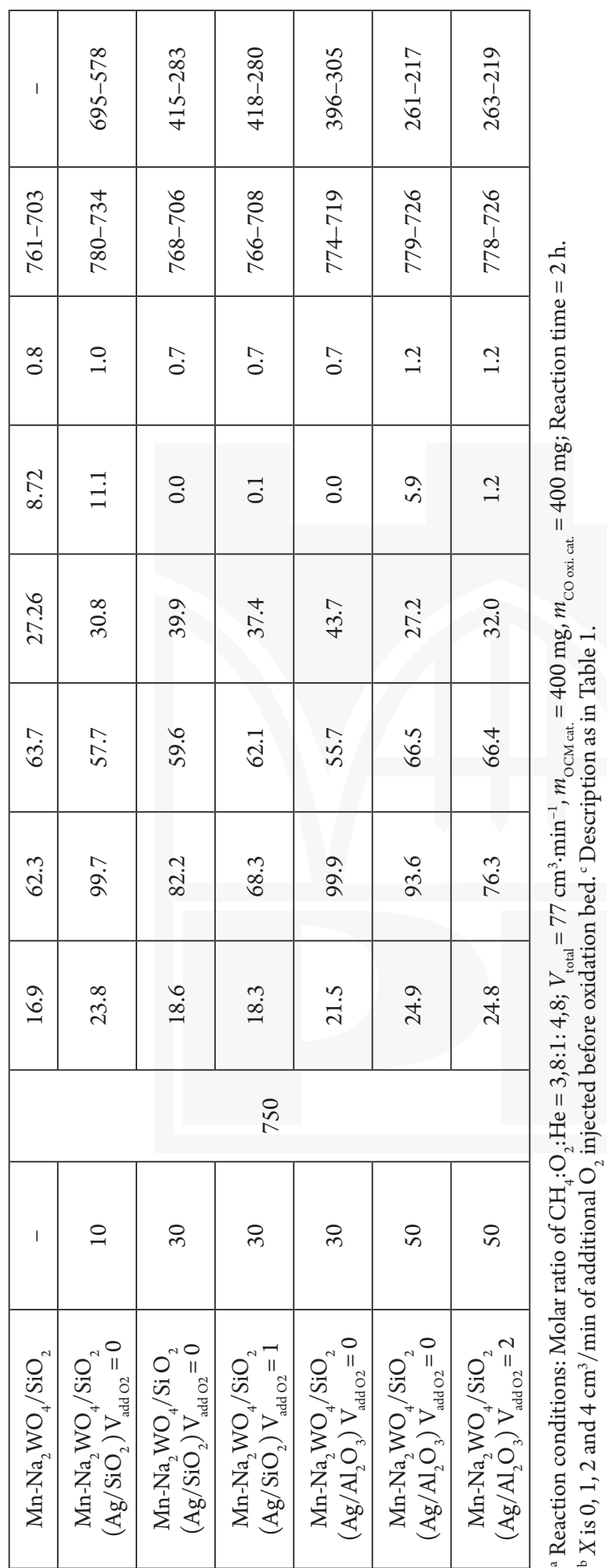




\section{Conclusions}

The integration of the OCM process with selective $\mathrm{CO}$ oxidation in a single reactor was investigated. It has been found that, under conditions suitable for the OCM process, controlling the selectivity in $\mathrm{CO}$ oxidation is very difficult. In most cases, $\mathrm{CO}$ and hydrocarbons are oxidized simultaneously over the oxidation bed. Preferential CO oxidation is possible only when the second oxidation bed is located at the end of the oven where the temperature is below $300^{\circ} \mathrm{C}$ and additional oxygen is injected before this bed.

\section{References}

[1] Oxidative Coupling of Methane, http://siluria.com/Technology/Oxidative_Coupling_ of_Methane (access: 11.04.16).

[2] Godini H.R., Xiao S., Jašo S., Stünkel S., Salerno D., Son N.X., Song S., Wozny G., Technoeconomic analysis of integrating the methane oxidative coupling and methane reforming processes, Fuel Processing Technology, vol. 106, 2013, 684-694.

[3] Michorczyk B., Ogonowski J., Michorczyk P., Węgrzyniak A., Katalizatory dla procesu utleniającego sprzęgania metanu, Przemysł Chemiczny, vol. 93, 2014, 1166-1173.

[4] Tiemersma T.P., Chaudhari A.S., Gallucci F., Kuipers J.A.M., van Sint Annaland M., Integrated autothermal oxidative coupling and steam reforming of methane. Part 1: Design of a dual-function catalyst particle, Chemical Engineering Science, vol. 82, 2012, 200-214.

[5] Tiemersma T.P., Chaudhari A.S., Gallucci F., Kuipers J.A.M., van Sint Annaland M., Integrated autothermal oxidative coupling and steam reforming of methane. Part 2: Development of a packed bed membrane reactor with a dual function catalyst, Chemical Engineering Science, vol. 82, 2012, 232-245.

[6] Tiemersma T.P., Kolkman T., Kuipers J.A.M., van Sint Annaland M., A novel autothermal reactor concept for thermal coupling of the exothermic oxidative coupling and endothermic steam reforming of methane, Chemical Engineering Journal, vol. 203, 2012, 223-230.

[7] Godini H.R., Xiao S., Kim M., Görke O., Song S., Wozny G., Dual-membrane reactor for methane oxidative coupling and dry methane reforming: Reactor integration and process intensification, Chemical Engineering and Processing, vol. 74, 2013, 153-164.

[8] Thybaut J. W., Marin G. B., Mirodatos C., Schuurman Y., van Veen A. C., Sadykov V. A., Pennemann H., Bellinghausen R., Mleczko L., A Novel Technology for Natural Gas Conversion by Means of Integrated Oxidative Coupling and Dry Reforming of Methane, Chemie Ingenieur Technik, vol. 86, 2014, 1855-1870.

[9] Godini H. R., Jaso S., Nghiem S. X., Görke O., Sadjadi S., Stünkel S., Song S., Simon U., Schomäcker R., Wozny G., Miniplant-Scale Analysis of Oxidative Coupling of Methane Process, Journal of Oil, Gas and Petrochemical Technology, vol. 2, 2015, 57-71.

[10] Skutil K., Taniewski M., Some technological aspects of methane aromatization (direct and via oxidative coupling), Fuel Processing Technology, vol. 87, 2006, 511-521. 
[11] Skutil K., Taniewski M., Indirect methane aromatization via oxidative coupling, products separation and aromatization steps, Fuel Processing Technology, vol. 88, 2007, 877-882.

[12] Qiu P., Lunsford J.H., Rosynek M.P., Steady-state conversion of methane to aromatics in high yields using an integrated recycle reaction system, Catalysis Letters, vol. 48, 1997, 11-15.

[13] Graf P.O., Lefferts L., Reactive separation of ethylene from the effluent gas of methane oxidative coupling via alkylation of benzene to ethylbenzene on ZSM-5, Chemical Engineering Science, vol. 64, 2009, 2773-2780.

[14] Czechowicz D., Skutil K., Tórz A., Taniewski M., An integrated process of oxidative coupling of methane and pyrolysis of naphtha in a scaled-up unit, Journal of Chemical Technology and Biotechnology, vol. 79, 2004, 182-186.

[15] Wensheng C., Grant P., Process for producing acetic acid and/or ethanol by methane oxidation, Patent. WO 2014/143865 A1, Pub.18.09.2014.

[16] Ghareghashi A., Ghader S., Hashemipour H., Theoretical analysis of oxidative coupling of methane and Fischer Tropsch synthesis in two consecutive reactors: Comparison of fixed bed and membrane reactor, Journal of Industrial and Engineering Chemistry, vol. 19, 2013, 1811-1826.

[17] Xu L., Xie S., Liu S., Lin L., Tian Z., Zhu A., Combination of $\mathrm{CH}_{4}$ oxidative coupling reaction with $\mathrm{C}_{2} \mathrm{H}_{6}$ oxidative dehydrogenation by $\mathrm{CO}_{2}$ to $\mathrm{C}_{2} \mathrm{H}_{4}$, Fuel, vol. 81, 2002, 1593-1597.

[18] Xu L., Xie S., Liu S., Lin L., Tian Z., Zhu A., Combination of $\mathrm{CH}_{4}$ oxidative coupling reaction with $\mathrm{C}_{2} \mathrm{H}_{6}$ oxidative dehydrogenation by $\mathrm{CO}_{2}$ to $\mathrm{C}_{2} \mathrm{H}_{4}$, Fuel, 81, 2002, 1593-1597.

[19] Michorczyk B., Suszyński K., Smoleń P., Hędrzak E., Utleniające sprzęganie metanu zintegrowane $w$ jednym reaktorze $z$ odwodornieniem etanu do etenu, Przemysł Chemiczny, vol. 95, 2016, 1936-1940.

[20] Rekoske J.E., Oxidative coupling of methane with carbon conservation, Uop Llc, Glenview. USA. Patent. US006096934A. Pub.1.08.2000.

[21] Kalakkunnath S,. Oxidative Coupling of Methane to Ethylene by Siluria Process, https:// chemical.ihs.com/PEP/Public/Reports/Phase_2014/RW2014-07/ (access: 11.04.16).

[22] Shi J., $\mathrm{Lu} \mathrm{Y.,} \mathrm{Hu} \mathrm{Ch}$. Effect of $\mathrm{CO}_{2}$ on the structural variation of $\mathrm{Na}_{2} \mathrm{WO}_{4} / \mathrm{Mn} / \mathrm{SiO}_{2}$ catalyst for oxidative coupling of methane to ethylene, Journal of Energy Chemistry, vol. 24, 2015, 394-400.

[23] Litawa B., Michorczyk P., Ogonowski J,. Influence of $\mathrm{CO}_{2}$ on the catalytic performance of $\mathrm{La}_{2} \mathrm{O}_{3} / \mathrm{CeO}_{2}$ and $\mathrm{CaO} / \mathrm{CeO}_{2}$ catalysts in the oxidative coupling of methane, Polish Journal of Chemical Technology, vol 15, 2013, 22-26.

[24] Xu Y., Yu L., Cai C., Huang J., Guo X., a study of the oxidative coupling of methane over $\mathrm{SrO}-\mathrm{La}_{2} \mathrm{O}_{3} / \mathrm{CaO}$ catalysts by using $\mathrm{CO}_{2}$ as a probe, Catal. Lett., vol. 35, 1995, 215-231.

[25] Kolts JH., Kukes S.G., Catalytic oxidation of carbon monoxide, USA. Patent. 4808394. Pub.28.02.1989.

[26] Kahlich M.J., Gasteiger A., Behm R.J., Kinetics of the Selective CO Oxidation in $\mathrm{H}_{2}$-Rich Gas on $\mathrm{Pt} / \mathrm{Al}_{2} \mathrm{O}_{3}$, Journal of Catalysis, vol. 171, 1997, 93-105.

[27] Mariño F., Descorme C., Duprez D., Noble metal catalysts for the preferential oxidation of carbon monoxide in the presence of hydrogen (PROX), Applied Catalysis B: Environmental, vol. 54, 2004, 59-66. 
[28] Oh S.H., Sinkevitch R.M., Carbon Monoxide Removal from Hydrogen-Rich Fuel Cell Feedstreams by Selective Catalytic Oxidation, Journal of Catalysis, vol. 142, 1993, 254-262.

[29] Avgouropoulos G., Ioannides T., Papadopoulou Ch., Batista J., Hocevar S., Matralis H.K., A comparative study of $\mathrm{Pt} / \gamma-\mathrm{Al}_{2} \mathrm{O}_{3}, \mathrm{Au} / \mathrm{a}-\mathrm{Fe}_{2} \mathrm{O}_{3}$ and $\mathrm{CuO}-\mathrm{CeO}_{2}$ catalysts for the selective oxidation of carbon monoxide in excess hydrogen, Catalysis Today, vol. 75, 2002, 157-167.

[30] Bethke G.K., Kung H.H., Selective CO oxidation in a hydrogen-rich stream over Au/ $\gamma$ $\mathrm{Al}_{2} \mathrm{O}_{3}$ catalysts, Applied Catalysis A: General, vol. 194, 2000, 43-53.

[31] Grisel R.J.H., Nieuwenhuys B.E., Selective Oxidation of CO, over Supported Au Catalysts, Journal of Catalysis, vol. 199, 2001, 48-59.

[32] Bond G.C., Thompson D.T., Gold-Catalysed Oxidation of Carbon Monoxide, Gold Bulletin, vol. 33, 2000, 41-50.

[33] Sun X., Su H., Lin Q. Han Ch., Zheng Y., Sun L., Qi C., $\mathrm{Au} / \mathrm{Cu}-\mathrm{Fe}-\mathrm{La}-\mathrm{Al}_{2} \mathrm{O}_{3}$ : a highly active, selective and stable catalysts for preferential oxidation of carbon monoxide, Applied Catalysis A: General, vol. 527, 2016, 19-29.

[34] Teng Y., Sakurai H., Ueda A., Kobayashi T., Oxidative removal of co contained in hydrogen by using metal oxide catalysts, International Journal of Hydrogen Energy, vol. 24, 1999, 355-358.

[35] Liu W., Flytzani-Stephanopoulos M., Total Oxidation of Carbon Monoxide and Methane over Transition Metal Fluorite Oxide Composite Catalysts: I. Catalyst Composition and Activity, Journal of Catalysis, vol. 153, 1995, 304-316.

[36] Liu W., Flytzani-Stephanopoulos M., Total Oxidation of Carbon-Monoxide and Methane over Transition Metal Fluorite Oxide Composite Catalysts: II. Catalyst Characterization and Reaction-Kinetics, Journal of Catalysis, vol. 153,1995, 317-332.

[37] Avgouropoulos G., Ioannides T., Matralis H. K., Batista J., Hocevar S., CuO-CeO mixed oxide catalysts for the selective oxidation of carbon monoxide in excess hydrogen, Catalysis Letters Vol. 73, 2001, 33-40.

[38] Hung-Kuan Lin H-K., Chiu H-Ch., Tsai H-Ch., Chien S-H., Wang Ch-B., Synthesis, characterization and catalytic oxidation of carbon monoxide over cobalt oxide, Catalysis Letters, vol. 88, 2003, 169-174.

[39] Wangcheng Z., Xinye Z., Yanglong G., Li W., Yun G., Guanzhong L., Synthesis of mesoporous $\mathrm{CeO}-\mathrm{MnO} x$ binary oxides and their catalytic performances for $\mathrm{CO}$ oxidation, Journal of Rare Earths, Vol. 32, 2014, 146-152.

[40] Li Z., Hound G.B., a Review on Complete Oxidation of Methane at Low Temperatures, Journal of Natural Gas Chemistry, vol. 12, 2003, 153-160.

[41] Stasinska B., Katalityczne utlenianie metanu z powietrza wentylacyjnego kopalń, https:// www.researchgate.net/publication/267544218 (access: 11.04.16).

[42] Qu Z., Cheng M., Huang W., Bao X., Formation of subsurface oxygen species and its high activity toward CO oxidation over silver catalysts, Journal of Catalysis, vol. 229, 2005, 446-458.

[43] Imamura S., Yamada H., Utani K., Combustion activity of $\mathrm{Ag} / \mathrm{CeO}$ composite catalyst, Applied Catalysis A: General, vol. 192, 2000, 221-226. 


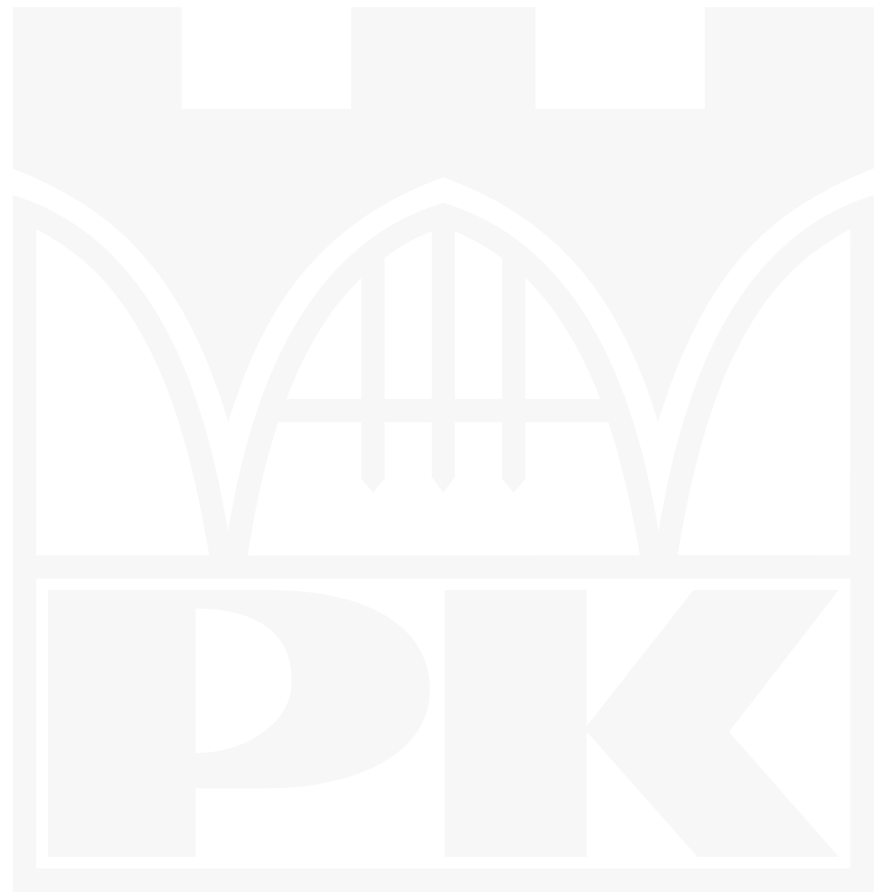

